\title{
Early-Age Thermal-Shrinkage Cracking in Deep Foundations
}

https://doi.org/10.2478/sgem-2021-0033

received August 31, 2021; accepted November 5, 2021.

\begin{abstract}
With the growing rate of urbanisation, deep foundations are playing an ever-larger role in the development of cities, reaching deeper than before to fulfil the requirements of new constructions. While current European standards include design procedures for structural and geotechnical design, they lack provisions for massive deep foundations with regard to early-age thermal effects. This paper presents aspects of the phenomenon especially important for deep foundations and discusses normative requirements that influence their thermal behaviour. Further, the paper describes the methods and results of the research carried out in the United Kingdom on 1.50-m-thick diaphragm walls of a deep circular shaft. Shaft features are described, as well as the materials used. The measurements were carried out using vibrating wire strain gauges coupled with temperature readings. The results presented refer to one of the test panels concreted in January 2020. The temperature results are analysed together with the influence of work scheduling on the readings. Strain results that indicate contractive behaviour of the test panel are investigated together with the possible causes leading to such readings. Plans and directions for future research are discussed.
\end{abstract}

Keywords: deep foundations; diaphragm walls; hydration heat; early-age thermal cracking; tremie concrete.

\footnotetext{
*Corresponding author: tukasz Grabowski, Warsaw University of Technology, Faculty of Civil Engineering, Al. Armii Ludowej 16, 00-637 Warsaw, Poland; Soletanche Polska Sp. z o.o., ul. Powązkowska 44c, 01-797 Warsaw, Poland, E-mail: lukasz.grabowski6.dokt@pw.edu.pl, ORCID: 0000-0002-1599-2407

Monika Mitew-Czajewska, Warsaw University of Technology, Faculty of Civil Engineering, Al. Armii Ludowej 16, 00-637 Warsaw, Poland, ORCID: 0000-0002-2651-2026
}

\section{Introduction}

\subsection{Deep foundations}

Deep foundations are structures whose main purpose is transferring the loads from the superstructure to competent soil layers that are below the excavation level. Nowadays, challenged by the ever-growing need for available spaces in cities, architects and engineers strive for reaching higher above or deeper below. This means that more and more facilities are designed underground to save the precious over ground for residential, working and commercial spaces. The tendency to move parking and transportation, observed worldwide, means that the applicability of deep foundations is rapidly expanding.

Additional purposes include soil and water retention for underground facilities like metro stations or car parks. Often, the roles are mixed, leading to mass reinforced concrete structures designed as both retaining walls and vertical load-transmitting elements. Notably, the most common type of deep foundations is made in the technology of diaphragm walls mostly due to its flexibility in application in multiple roles. One of the cases of mixedrole deep foundations was thoroughly described by Siemińska-Lewandowska et al. (2013), focusing primarily on the design and monitoring aspects and providing the methodology of geotechnical design used.

\subsection{Deep foundations- general design considerations}

The design of underground structures in Poland is currently made according to Eurocodes. Contrary to the now-withdrawn Polish codes, the European Standards give rules on verifications of limit states and external factors that should be taken into consideration in the analysis, but give a lot of freedom for the designer to choose the design method.

Basics of geotechnical design of deep foundations are, therefore, obtained mainly in literature and articles. Methods for designing deep excavations can be found 


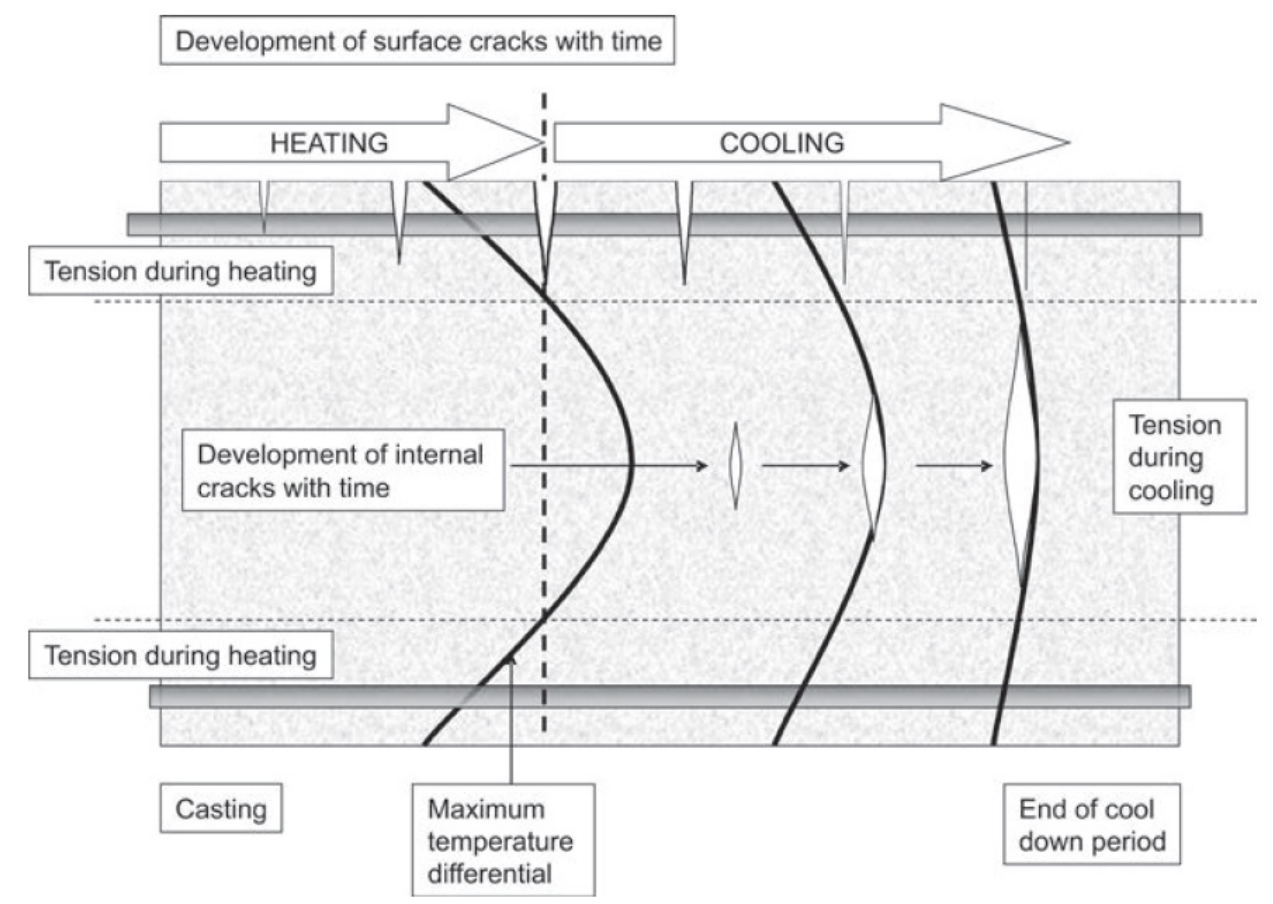

Figure 1: Thermal cracking development in time (Bamforth, 2007, 2018).

in Siemińska-Lewandowska (2010), while plenty of other works analyse and discuss the design of deep foundations (Poulos, 2020; Siemińska-Lewandowska \& Mitew-Czajewska, 2008) and their effects on surrounding buildings and infrastructure (Mitew-Czajewska \& Tomczak, 2019; Mitew-Czajewska \& SiemińskaLewandowska, 2016).

Structural design is then carried out according to the respective standards, based on the type of the structure. In the case of mass deep foundations, the majority is made of reinforced concrete. While Eurocode 2 constitutes a relatively exhaustive source of design rules and recommendations, it does not cover the rules specific for designing early-age thermal effects in mass concrete (Klemczak \& Żmij, 2021).

\section{Thermal aspects of deep foundations design}

Thermal effects that arise in deep foundations are driven by the cement hydration reaction that occurs in all concrete elements. Due to the low thermal conductivity of concrete, concrete elements with large dimensions are especially susceptible to reaching high temperature gradients (Klemczak \& Batog, 2016).

\subsection{Internal restraint}

In massive concrete, the conditions in the core of the element during curing are close to adiabatic, while the outside exchanges heat with the environment from the moment of concreting (Klemczak \& Batog, 2016). The resulting temperature gradient in concrete section means differences in strains and leads to an effect called internal restraint - the integrity of an element restrains free thermal expansion of concrete section (Bamforth, 2007). For sufficiently high thermal strains, the tensile capacity of concrete is surpassed. This leads to the phenomenon known as early-age thermal-shrinkage cracking.

Cracking occurs in the edges of the element in the heating stage and in the centre during the cooling stage. The cycle is presented in Fig. 1. Because the deformation modulus of concrete rises during the cycle and is higher during cooling than during heating, after reaching thermal equilibrium, the section is subject to tensile strains in its central part (Bamforth, 2018). This is an important notion, especially for the design of retaining walls subject to water pressure. The existence of deep cracks facilitates water infiltration to the inside of the underground structure. An uncracked element with residual tensile stresses inside will propagate bending cracks deeper into the section. 


\subsection{External restraint}

Another source of early-age thermal-shrinkage cracking is linked to external restraint - an effect much more often observed in engineering practice. Thermal contraction and shrinkage of an element are restrained by external sources. Most commonly, the source of external restraint is an adjoining element, for example, foundation slab to the wall of a tank (edge restraint) or foundation slab plot poured between the already finished plots (end restraint) (Zych, 2018). In deep foundations, the role of the restraining agent is taken by the soil and the adjoining primary elements. Both the reports of other authors (Liou, 1999) and own observations suggest that secondary elements are more susceptible to cracking.

\subsection{Deep foundations- thermal considerations}

In engineering practice, designers try to mitigate the effects of hydration heat and shrinkage, rather than design additional reinforcement to limit crack width. The countermeasures focus on limiting the heat discharge amount and rate, element dimensions and adjusting the work schedule. The amount of heat generated is reduced by the use of low-heat cements (De Schutter, 1999). Lower heat discharge is usually obtained by substitution of part of Portland cement with ground granulated blast furnace slag (GGBS) or pulverised fly ash (PFA). Pour sizes are adjusted to limit the risk of thermal-shrinkage cracking caused by restraint coming from friction with soil and edge restraint from neighbouring elements. The last factor taken into account is the moment of removing the formwork or insulation of an element, especially in cold weather (Woyciechowski et al., 2020).

In deep foundations, many of these measures are impossible or impractical to apply. In Poland, concrete for tremie concreting is commonly based on CEM III/A 42,5N blast furnace cements. Their heat of hydration measured is in the range of $235-250 \mathrm{~J} / \mathrm{g}$, which is in line with the normative definition of low-heat cement not exceeding the value of $270 \mathrm{~J} / \mathrm{g}$, as specified in the standard (PKN, 2012). Compared with the heat of hydration of CEM I $42.5 \mathrm{~N}$ in the order of $300 \mathrm{~J} / \mathrm{g}$, the reduction is significant (Fig. 2.).

On the other hand, the concrete for special geotechnical works requirement of minimum cement content specified in annex D of PN-EN 206 (PKN, 2016) is in the range of $350-400 \mathrm{~kg} / \mathrm{m}^{3}$, depending on the aggregate diameter. The value of $400 \mathrm{~kg} / \mathrm{m}^{3}$ (for $\mathrm{D}_{\max }=$ $16 \mathrm{~mm}$ ), which is typical in engineering practice, exceeds

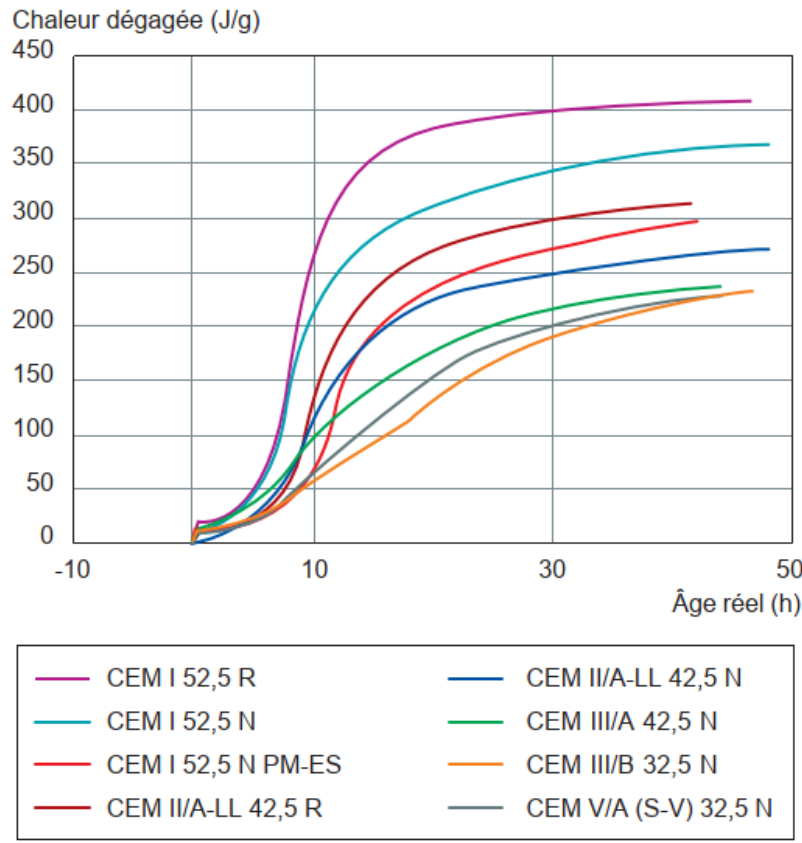

Figure 2: Hydration heat development for selected types of cement (LCPC, 2007).

all requirements for general use structural concrete, based on exposure classes ranging from 260 to $360 \mathrm{~kg} / \mathrm{m}^{3}$. The direct consequence is that the use of low-heat cement is offset by the required amount of binder that is much higher than necessary in terms of both durability and strength. One could consider the use of very low-heat cements (hydration heat not exceeding $220 \mathrm{~J} / \mathrm{g}$ (PKN, 2015)), but the longer time needed to reach target strength may be impractical on the construction site.

Execution technologies in deep foundation works do not allow any significant way to influence the sizes of pours. Any cold joint inside a pile or diaphragm wall panel is considered a serious defect. Both large diameter piles and diaphragm walls must, therefore, be concreted in one pour. In deep foundations design, the depth and thickness (diameter) of elements are derived directly from static analysis and are driven by vertical loads, earth pressures or a combination of both. The remaining dimension, the length of the panel, is generally smaller than depth and bigger than thickness, which means that it has little influence on thermal effects. Internal restraint is highly dependent on the thickness of the element and extreme temperature gradient within the section. External restraint is dependent on shrinkage and thermal contraction resisted by soil and neighbouring elements, and is therefore influenced the most by the depth of the element.

All the factors considered above lead to the conclusion that early-age thermal-shrinkage cracking should occur 
in massive deep foundations similar to general concrete structures. On the other hand, possibilities of mitigation of the phenomenon are limited, as typical countermeasures are either impractical or already incorporated into the technological regime. Due to the unusual conditions of work execution, it is necessary to separate the internal and external restraint effects. The internal restraint is common for all concrete structures, while the influence of external restraint through soil friction mobilisation is specific to deep foundations.

Bearing this in mind, a series of measurements were carried out on the Thames Tideway project in London, United Kingdom by Bachy Soletanche Ltd. The methods and results of the measurements are presented in the subsequent sections.

\section{Temperature and strain measurements in diaphragm walls}

\subsection{Site description}

The measurements took place in 2020 on several instrumented diaphragm wall panels on a deep circular shaft located in London. Data discussed in this article were already subject to an analysis by Sajadi (2020), with regard to temperature data only.

The circular shaft (Fig. 3) was composed of 30 panels, primary and secondary alternating. The thickness of each panel was $1.50 \mathrm{~m}$, length $2.80 \mathrm{~m}$ and depth $74.10 \mathrm{~m}$. The overall theoretical volume of a single pour was $300 \mathrm{~m}^{3}$. The shape of the primary panels is trapezoidal in Fig. 3 because during the construction of secondary panels, the hydrofraise cuts into the primary panel to form a concrete-concrete joint.

\subsection{Measurement setup and timeline}

The vibrating wire strain gauges in the form of sister bars, equipped with thermistors were installed in five levels, with six sensors in each. The layout of gauges is presented in Fig. 4. In the middle, there is a circle marking the position of a concreting tremie pipe. The levels of installation of sensors are shown in Table 1; sensors were marked with codes comprising level (L1-L5) and sensor position (A-F). Attention should be brought to the fact that sensors $\mathrm{E}$ and $\mathrm{F}$, although seemingly at the edge of the reinforcement cage, are deeply embedded into the panel

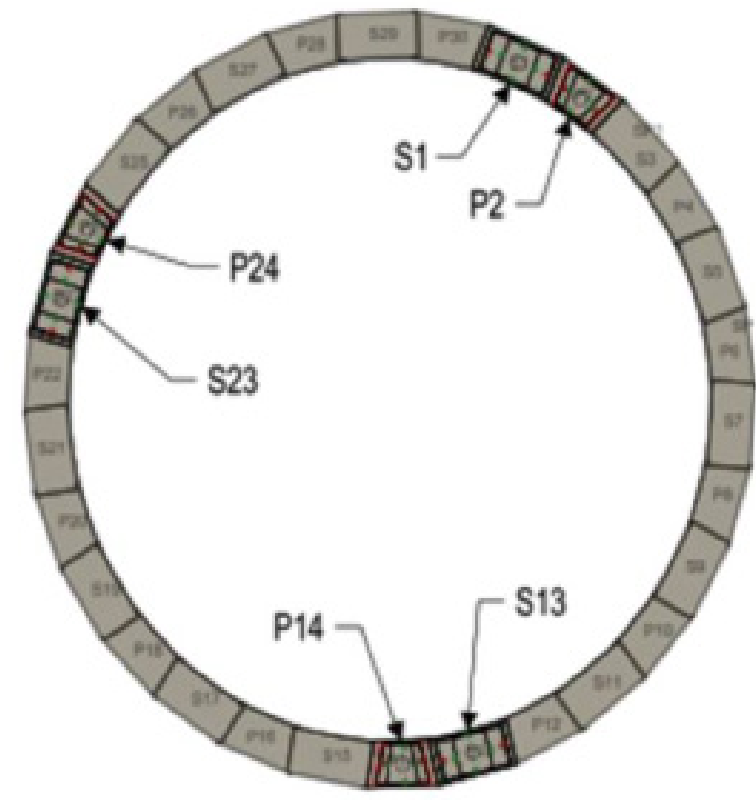

Figure 3: Circular shaft in top view.

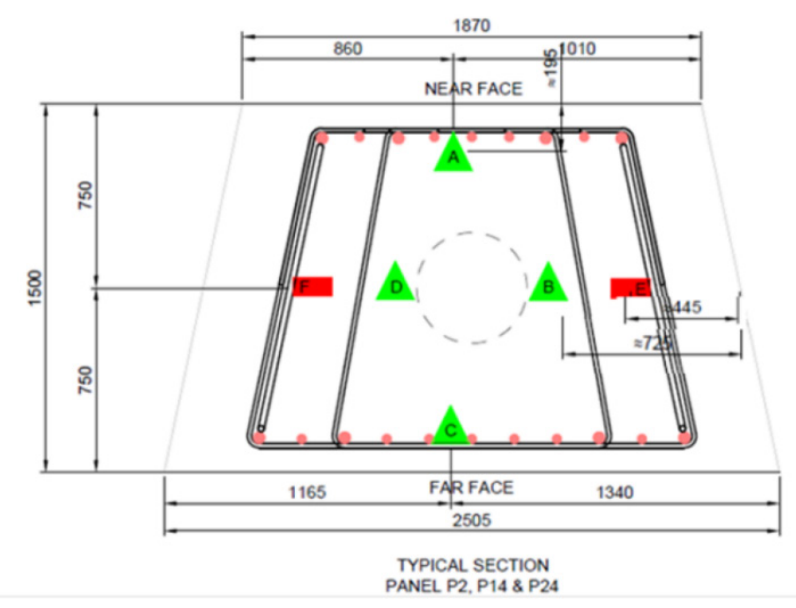

Figure 4: Location of gauges in instrumented panels (Sajadi, 2020).

due to the fact that its final shape will be the result of the excavation of adjacent secondary panels.

Data logging started several hours before the concreting ended. Analysis of the data and recorded times of the end of concreting suggests that at least some sensors were not embedded in concrete at the time of the start of data collection. Table 2 summarises the execution times for primary panel P24.

The measurements were collected automatically for both temperature and strains with the time step of 1 hour. The shaft is still in construction and measurements are still collected. 
Table 1: Measurement levels.

\begin{tabular}{ll}
\hline Measurement level & Depth $(\mathrm{m})$ \\
\hline L1 & 24.6 \\
L2 & 34.6 \\
L3 & 39.6 \\
L4 & 49.6 \\
L5 & 64.6 \\
\hline
\end{tabular}

Table 2: Important timeline events for the instrumented panel P24.

\begin{tabular}{|c|c|c|c|}
\hline Panel & Event & Date, time & $\begin{array}{l}\text { Time elapsed } \\
\text { from the start of } \\
\text { concreting (days) }\end{array}$ \\
\hline \multirow[t]{4}{*}{$\begin{array}{l}\text { P24 } \\
\text { (instrumented) }\end{array}$} & $\begin{array}{l}\text { Excavation } \\
\text { start }\end{array}$ & $\begin{array}{l}23 / 01 / 2020, \\
10: 45\end{array}$ & -6 \\
\hline & $\begin{array}{l}\text { Excavation } \\
\text { end }\end{array}$ & $\begin{array}{l}27 / 01 / 2020 \\
16: 45\end{array}$ & -2 \\
\hline & $\begin{array}{l}\text { Concreting } \\
\text { start }\end{array}$ & $\begin{array}{l}29 / 01 / 2020, \\
08: 22\end{array}$ & 0 \\
\hline & $\begin{array}{l}\text { Concreting } \\
\text { end }\end{array}$ & $\begin{array}{l}29 / 01 / 2020, \\
15: 45\end{array}$ & 0 \\
\hline \multirow[t]{4}{*}{$\begin{array}{l}\text { S23 (counter- } \\
\text { clockwise side) }\end{array}$} & $\begin{array}{l}\text { Excavation } \\
\text { start }\end{array}$ & $\begin{array}{l}28 / 02 / 2020 \\
08: 30\end{array}$ & 30 \\
\hline & $\begin{array}{l}\text { Excavation } \\
\text { end }\end{array}$ & $\begin{array}{l}04 / 03 / 2020, \\
15: 00\end{array}$ & 35 \\
\hline & $\begin{array}{l}\text { Concreting } \\
\text { start }\end{array}$ & $\begin{array}{l}06 / 03 / 2020 \\
07: 43\end{array}$ & 37 \\
\hline & $\begin{array}{l}\text { Concreting } \\
\text { end }\end{array}$ & $\begin{array}{l}\text { 06/03/2020, } \\
19: 10\end{array}$ & 37 \\
\hline
\end{tabular}

\subsection{Concrete}

Selected concrete properties, as supplemented by the contractor, are summarised in Table 3:

\section{Results and discussion}

The measurement results for strains and temperatures were collected and reduced to a 90-day period due to the volume of the data and the importance of the early period of concrete curing for this study. The data obtained are presented on the time scale in days elapsed from the beginning of concreting.

Notably, there were two instances of data corruption errors for both temperature and frequency and one 10-day period of missing temperature readings from 24 February
Table 3: Concrete properties.

\begin{tabular}{lll}
\hline Parameter & Value & Unit \\
\hline $\begin{array}{l}\text { Cement content (CEM type I, ASTM } \\
\text { compliant) }\end{array}$ & 150 & $\mathrm{~kg} / \mathrm{m}^{3}$ \\
$\begin{array}{l}\text { Supplementary cementitious material } \\
\text { content (GGBS) }\end{array}$ & 310 & $\mathrm{~kg} / \mathrm{m}^{3}$ \\
$\begin{array}{l}\text { Superplasticisers and retarders } \\
\text { Density, } \rho\end{array}$ & $4.9-5.3$ & $\mathrm{l} / \mathrm{m}^{3}$ \\
Specific heat, $c_{0}$ & 2400 & $\mathrm{~kg} / \mathrm{m}^{3}$ \\
\hline
\end{tabular}

GGBS, ground granulated blast furnace slag

to 5 March 2020. There were also several cases of data corruption for individual sensors, probably due to a sensor internal failure. It affected the temperature readouts (L3D) or frequency readings (L2B, L3B, L3D, L3E, L3F, L4E, L5B, L5D). More failures happened below 35-m depth, which points to fresh concrete pressure as a possible reason for some of those failures.

\subsection{Recorded temperatures}

The temperature readings across all measurement levels displayed similar curves with little variation with depth and distinct maxima regarding location within a measurement level. Fig. 5 shows temperature evolution in level L1 and it is representative for all measurement levels. Based on the analysis of the data, it can be stated that the maximum temperature is reached after 2.5-4 days after the start of concreting. Conforming to expectations, the highest temperatures are obtained in sensors $\mathrm{B}$ and $\mathrm{D}$, then $\mathrm{E}$ and $\mathrm{F}$, and finally A and C. Additionally, peak temperatures are reached slightly earlier on deeper levels with the difference of several hours between L1 and L5, which is consistent with the age of concrete poured on those levels being separated by concreting time.

The dips and peaks observed after 37-50 days from concreting are the effect of the execution of adjacent panel S23 on the counterclockwise side. The continuous lines on Fig. 5 mark sensors L1D and L1F that were installed nearest to S23, but the effect can be seen for each of the sensors. Contrary to the instrumented panel, the local temperature extrema are shifted in time with sensors farther from S23 panel recording lower values later in time than those closer, which is consistent with the effect of heat dissipation through the P24 panel. The maximum temperature reached was $49^{\circ} \mathrm{C}$ in L4B. The maximum temperature gradient was $10^{\circ} \mathrm{C}\left(17^{\circ} \mathrm{C} / \mathrm{m}\right)$ between $\mathrm{B}$ and $\mathrm{A}$ 


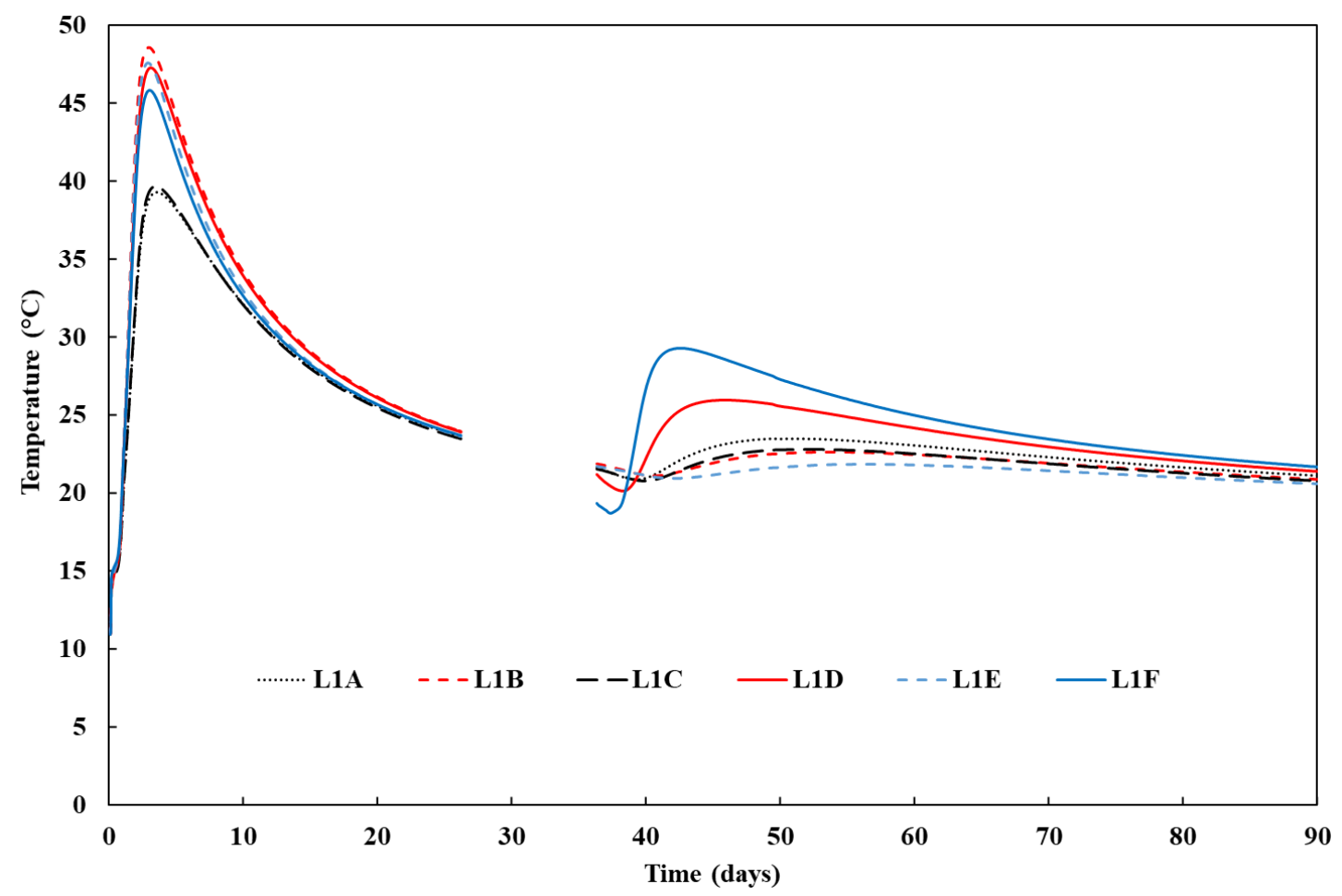

Figure 5: Temperature development in time for L1.

gauges in the heating stage. Similarly, gradient values of $9^{\circ} \mathrm{C}\left(11^{\circ} \mathrm{C} / \mathrm{m}\right)$ were found between $\mathrm{F}$ and $\mathrm{A}$ or $\mathrm{C}$ gauges in heat dissipation from the S23 stage.

\subsection{Recorded vibrating wire data}

The vibrating wire data were collected in the format of 'digits', which are quantities obtained from direct frequency measurement, but immediately transformed by raising the frequency to the power of 2 and usually dividing by a scaling factor. The purpose of this procedure is to obtain measurements in a format that scales linearly with strain. The natural frequency of a vibrating wire is given by equation (1):

$$
f=\frac{1}{2 L} \cdot \sqrt{\frac{\sigma}{\rho}}
$$

where $\mathrm{L}=$ length of vibrating wire $(\mathrm{m}), \sigma=$ wire stress $(\mathrm{N} /$ $\left.\mathrm{m}^{2}\right), \rho=\operatorname{density}\left(\mathrm{kg} / \mathrm{m}^{3}\right)$ and $\mathrm{f}=$ natural frequency $(\mathrm{Hz})$.

By substituting stress with Hooke's Law and transforming this equation for strain $(\varepsilon)$, equation (2) is obtained:

$$
\varepsilon=\frac{4 L^{2} \rho}{E} \cdot f^{2}=k \cdot f^{2}
$$

where $\mathrm{E}=$ Young's modulus of the wire $\left(\mathrm{N} / \mathrm{m}^{2}\right), \varepsilon=$ strain $(-)$ and $\mathrm{k}=$ vibrating wire constant.

The final step in transformation is the separation into 'digits' $\mathrm{R}$ and sensor constant $\mathrm{K}$, provided by the manufacturer. The constant $\mathrm{K}$ and conversion factor for digits are chosen, so that the result is already obtained in units consistent with sensors' measurement range, usually microstrain, $\left(\mu \varepsilon=\varepsilon \cdot 10^{-6}\right)$, as shown in equation (3):

$$
\mu \varepsilon=\frac{4 L^{2} \rho}{1000 \cdot E} \cdot \frac{f^{2}}{1000}=K \cdot R
$$

The sensor is always installed with the wire under prestress, so the actual change in strain state is calculated according to equation (4) as the difference between current measurement and initial measurement, be it in 'digits' or Hertz. 


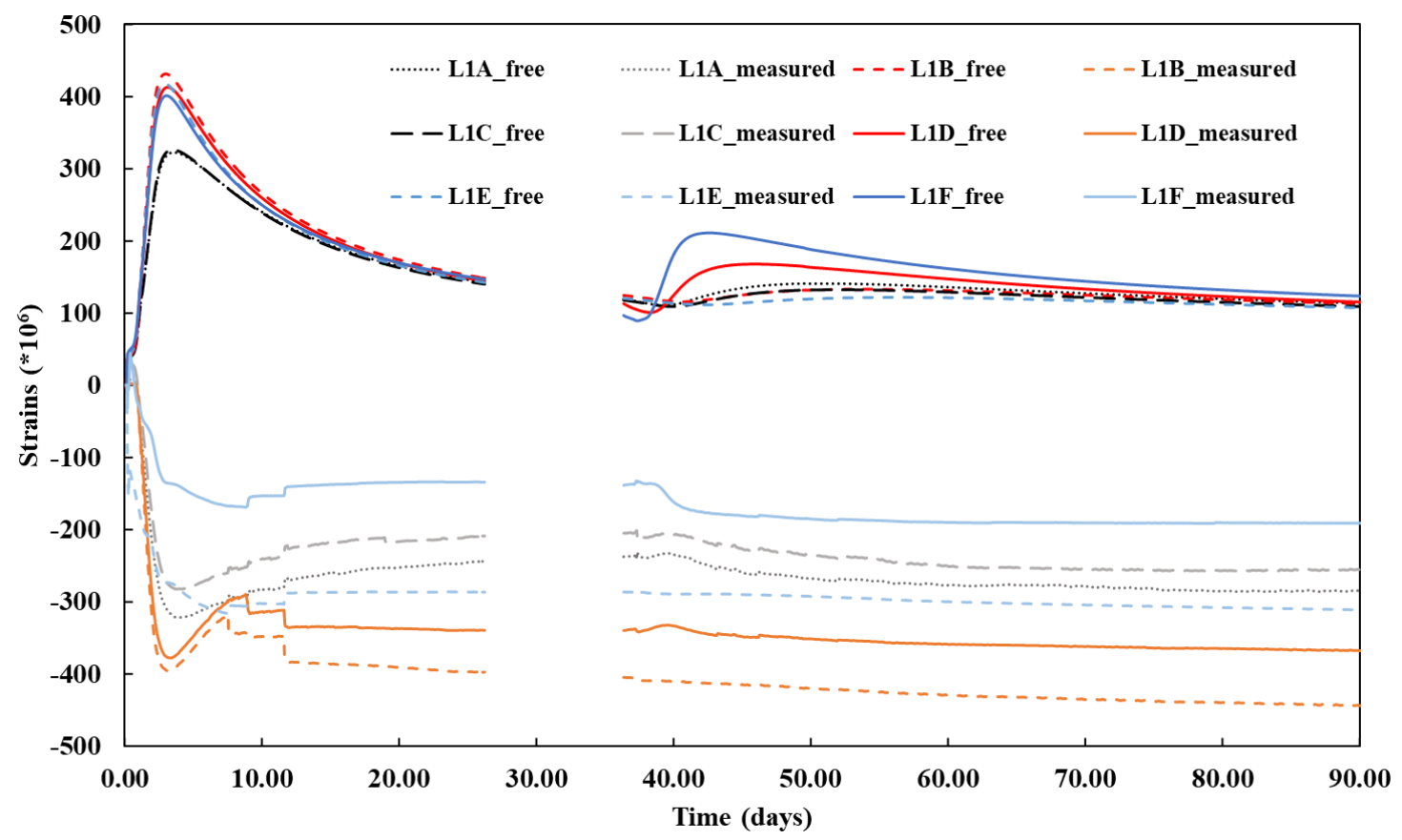

Figure 6: Free thermal strains and measured strains in time for L1.

$$
\mu \varepsilon=K \cdot\left(R_{1}-R_{0}\right)=K_{f} \cdot\left(f_{1}^{2}-f_{0}^{2}\right)
$$

The results of the above transformations are shown in Figs 6-8, paired with corresponding calculations of free thermal strains that were obtained using equation (5), assuming the thermal expansion coefficient as $\alpha_{\mathrm{t}}=11.5 \cdot 10^{-6}\left(1 /{ }^{\circ} \mathrm{C}\right)$.

$$
\varepsilon_{\text {free }}=\alpha_{t} \cdot\left(T_{1}-T_{0}\right)
$$

For lack of more precise data, this particular value is taken as a middle value of the range stretching from $9 \cdot 10^{-6}\left(1 /{ }^{\circ} \mathrm{C}\right)$ to $13.7 \cdot 10^{-6}\left(1 /{ }^{\circ} \mathrm{C}\right)$, given by Bamforth (2018) for glacial gravel. It is worth noting that it is significantly higher than the value of $10.0 \cdot 10^{-6}\left(1 /{ }^{\circ} \mathrm{C}\right)$, recommended in Eurocode 2 (PKN, 2008) and representative for a broader range of aggregates. Deep foundations are specifically done with coarse aggregates that, to limit segregation, are preferred to be naturally rounded, like gravels.

The results shown above are limited to measurement levels L1, L2 and L4 because L3 and L5 presented too much corrupt data to analyse.

As can be seen, all sensors recorded contraction in the first stages of concrete setting, and most have not recorded expansion at all, which is expected as a result of an increase in concrete temperature.

\subsection{Absolute values analysis and discussion}

In terms of absolute values, the recorded strains are of the correct order of magnitude compared to free thermal strains (Fig. 9). Depending on the location, the gauges recorded strains at a maximum temperature in the range of $300-400 \mu \varepsilon$. These values are very close to the calculated free thermal strains, but are always smaller. This indicates that the crucial parameter in assessing the restrained strains with concrete temperature rise measured with a precision of $\pm 1^{\circ} \mathrm{C}$ is thermal expansion coefficient that displays a much higher variability according to literature and is variable throughout the curing process.

This may also cause difficulties in separating internal and external restraint. In the heating stage, all results lower than calculated free strains would indicate the important role of external restraint. Assuming a lower value of thermal expansion coefficient might result in section core strains being smaller and section edge being higher, which is consistent with dominant internal restraint. Finally, the value of thermal expansion coefficient resulting in measured strains higher than free strains indicates external application of tensile force or, in the absence of such load, a bottom boundary of thermal expansion coefficient. In the discussed case for L1, it amounts to $9.9 \cdot 10^{-6}\left(1 /{ }^{\circ} \mathrm{C}\right)$, which is $86 \%$ of the assumed value. 


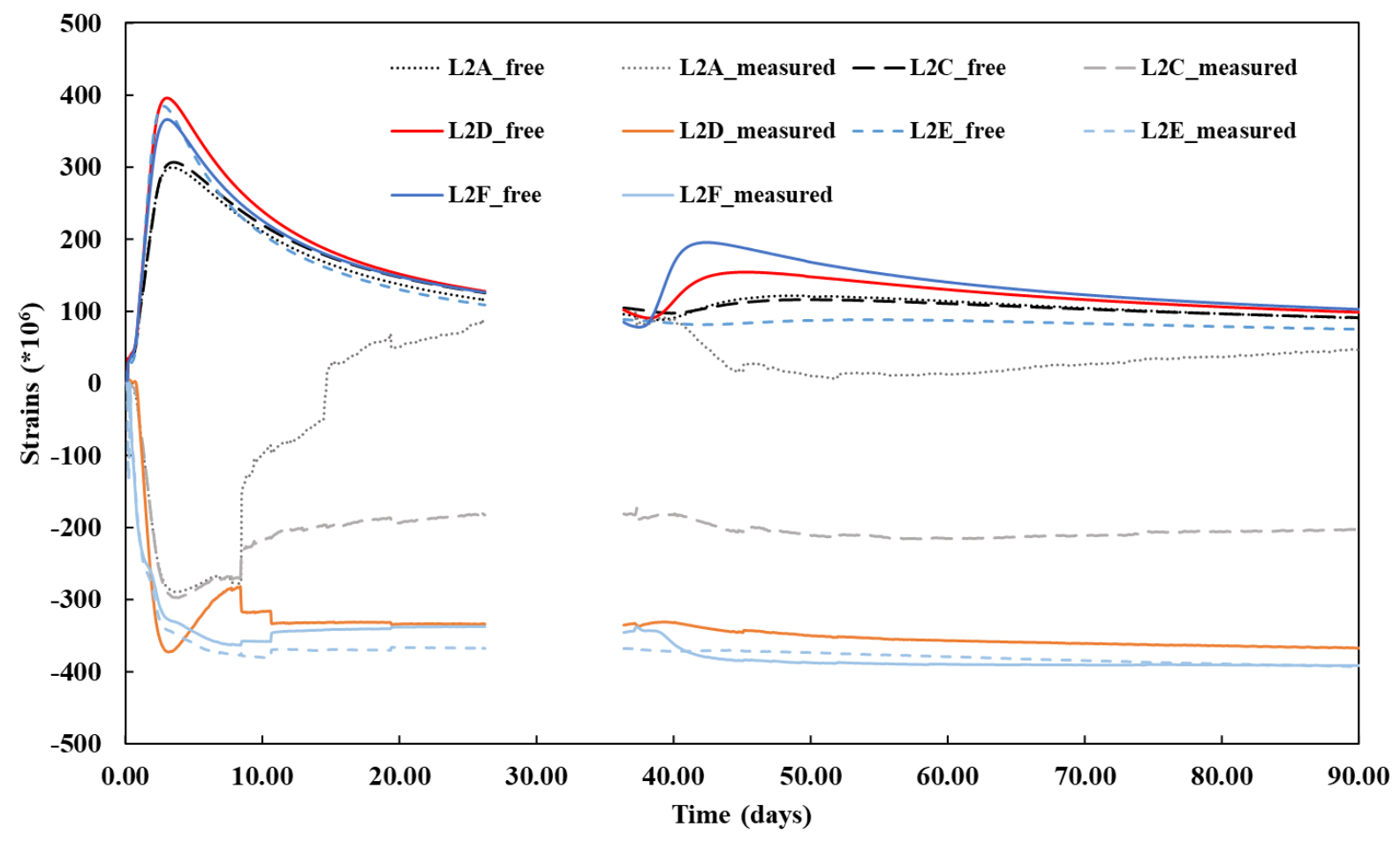

Figure 7: Free thermal strains and measured strains in time for L2.

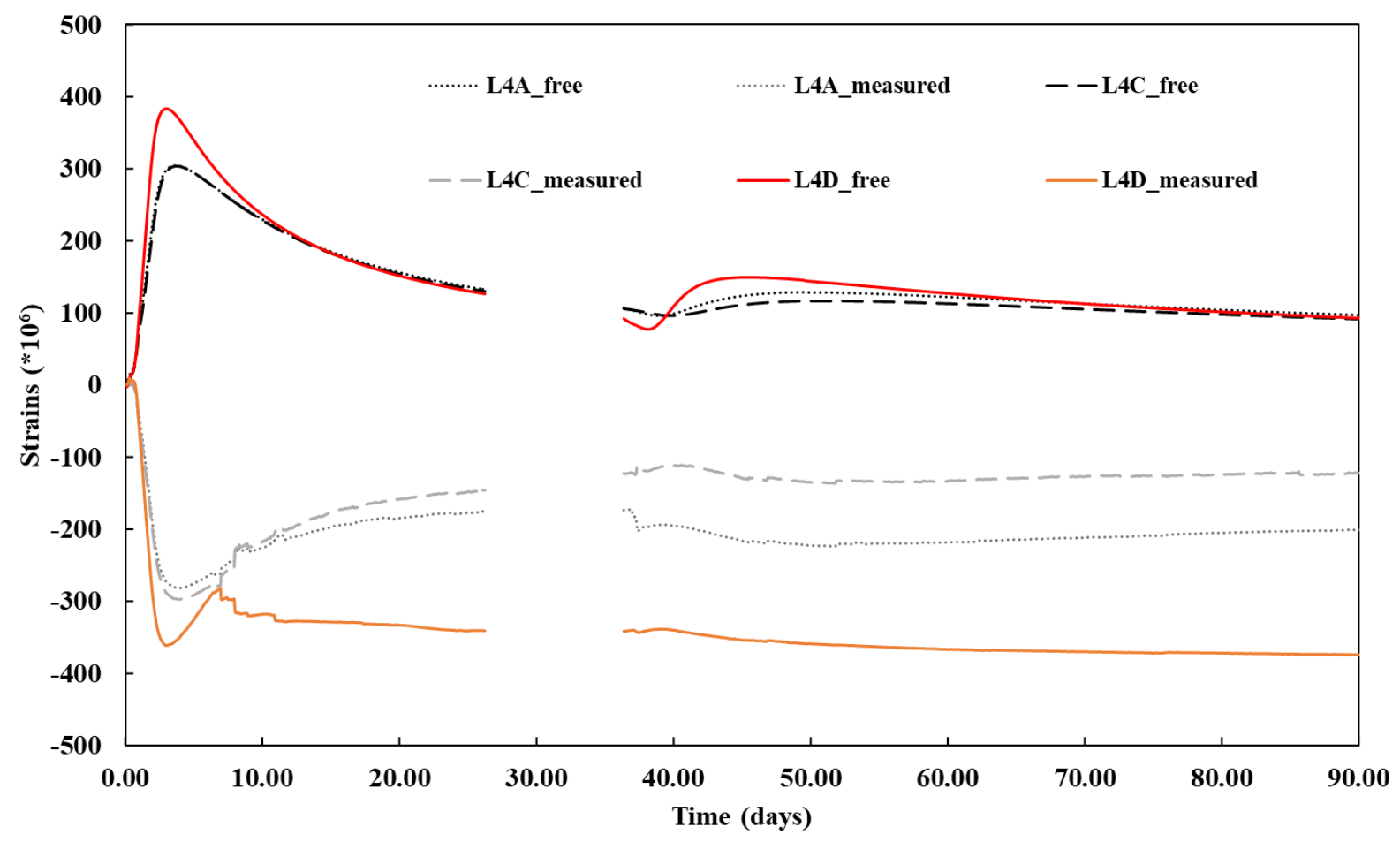

Figure 8: Free thermal strains and measured strains in time for L4. 


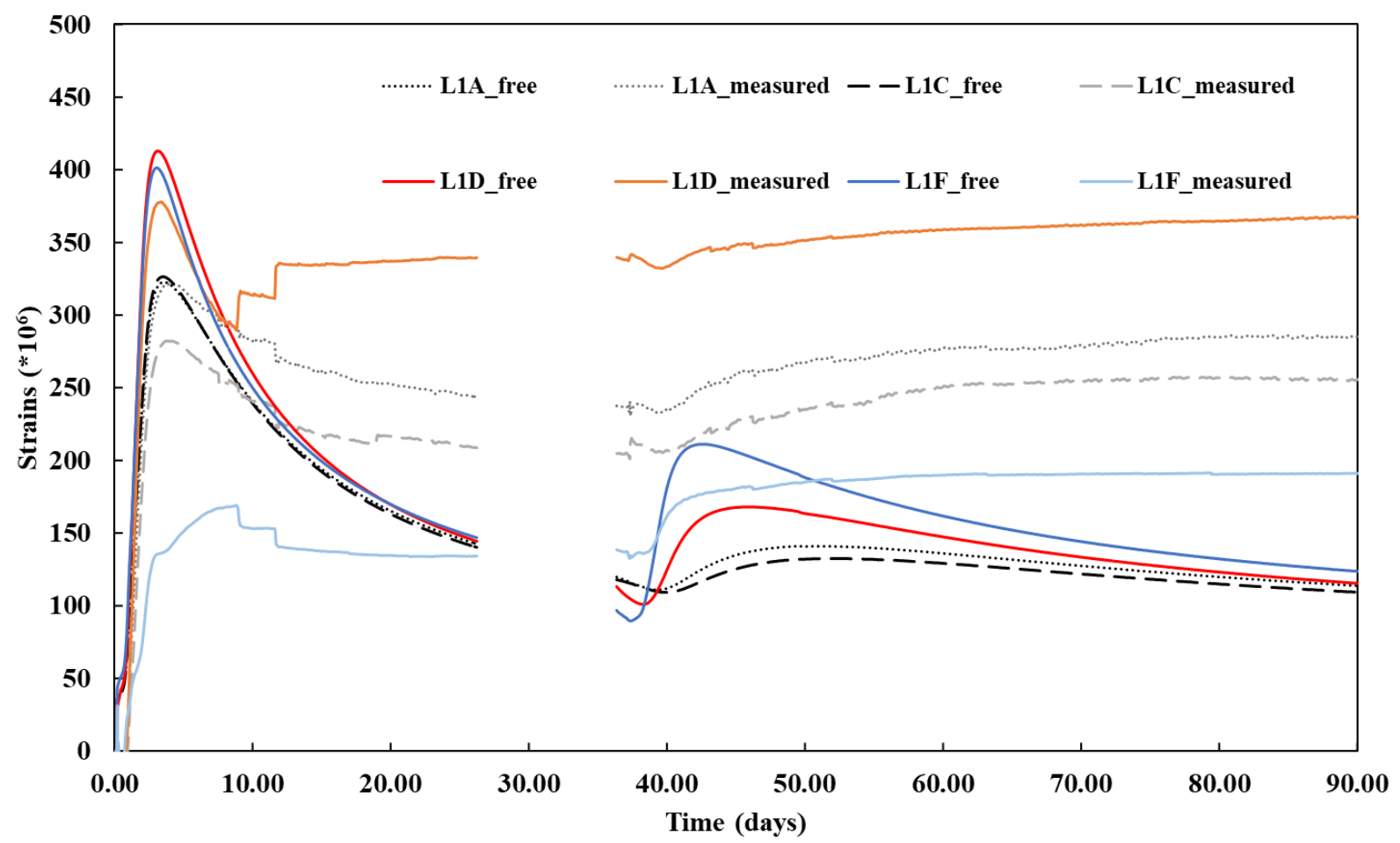

Figure 9: Absolute values of recorded strains and free thermal strains in time for L1.

\subsection{Discussion on the contractive behaviour results}

The results indicating contraction may be caused by either an error in the data transformation or an effect earlier unaccounted for and significant for deep foundations.

Regarding the data transformation error, it is unlikely to be caused by a simple accidental sign change in the data collection programme since the measured strains are calculated from differences in readings. No raw frequency data is available, but frequency data back-calculated from 'digits' as per equation (3) indicate that the frequency of vibrations is lower than the initial reading. This means a decrease of stress in the wire as in equation (1) and, therefore, contraction of the element. The expectation is that the instrumented panel would expand due to the temperature rise, presenting differences in strains across its thickness, and therefore indicating the effect of restrained strains of either internal or external nature.

On the other hand, the shape of the measured strain curve closely follows the shape of the temperature curve in early stages and reaches its extremum together with the temperature of the section. The results, therefore, resemble the expected characteristic of the strain, but with a changed sign, which, as explained before, is unlikely to be a simple error of -1 multiplication.

As for the other causes of possible contraction, the external loads are unlikely at this age and there are no reports of any such events from the site. The shrinkage of concrete, although omitted for readability reasons in the data on Figs $6-8$, is a major factor of early-age effects in concrete. In the analysed case, however, it is not important enough to offset the effect of thermal expansion. According to formula (3.12) given in Eurocode 2 (PKN, 2008), the maximum value of autogenic shrinkage for $\mathrm{C} 40 / 50$ concrete is $\varepsilon_{\text {ca }}(\infty)=75 \mu \varepsilon$. This means that autogenic shrinkage will never overcome thermal effects in this case. The drying shrinkage has more potential in this regard, but is offset by the relative humidity of the environment. Nominal drying shrinkage calculated according to formulae (B.11), (B.12), (3.9) and (3.10) in Eurocode $2(\mathrm{PKN}, 2008)$ is equal to $\varepsilon_{\mathrm{cd}}(\infty)=\mathrm{k}_{\mathrm{h}} \varepsilon_{\mathrm{cd}}(0)=50 \mu \varepsilon$ for relative humidity $(\mathrm{RH})=95 \%$. Both types of shrinkage add up to contraction strains of the order of $120 \mu \varepsilon$, but after infinite time. At the age of 3 days, total shrinkage adds up to no more than $20 \mu \varepsilon$, which is not sufficient to overcome thermal effects that amount to 15 times more.

Another possible explanation of such results could be the effect of bleeding and plastic settlement in the 
concrete mix. High hydrostatic pressure of fresh concrete column is acting as an external pressure (Larisch, 2019) and is prone to squeezing free water from the mix. In the discussed case at the depth of L1 $(24.6 \mathrm{~m})$, the pressure exerted by the concrete reaches $600 \mathrm{kPa}$ and the difference in vertical pressures caused by exchanging of bentonite slurry with concrete is close to $350 \mathrm{kPa}$. Such a high pressure change can cause part of the water to be expelled from the mix. This can cause both significant volume changes and defects in concrete such as channelling or piping effects. There is, however, little information on aggregate composition to support the claim of the mix being susceptible to bleeding and plastic settlements. Additionally, the effects of bleeding and plastic settlement are limited to the time scale when concrete is still in a workable state, and therefore cannot explain concrete behaviour at the time of 3 days from concreting.

\section{Conclusions}

Early-age thermal cracking is a phenomenon that can potentially prove challenging for deep and massive underground structures. Due to particularities stemming from technological process requirements, some typical countermeasures cannot be applied while others are impractical. For this reason, a better understanding of the influence of thermal-shrinkage effects on the performance of deep foundations is necessary.

In terms of temperature results, the values reached did not surpass $50^{\circ} \mathrm{C}$ and temperature gradients between the core of the section and its edge did not surpass $10^{\circ} \mathrm{C}$. Notably, high temperature gradient within section also occurred during the curing of the adjacent panel. This points to the need of taking the time schedule of the works into consideration.

The recorded strain results obtained indicated contraction of the element rather than expansion. A simple error in the data transformation seems unlikely due to the operating principle of vibrating wire gauges. On the other hand, no clear reason for such results could be found based on available data. Nevertheless, the value of the thermal expansion coefficient was found to be an important factor influencing the calculations of restraint and blurring the distinction between internal and external restraint. Additionally, the possible effects of fresh concrete column settlement and concrete bleeding should be investigated, as being particular to deep foundations and possibly influencing the results.
Further research will be carried out in this direction, concentrating on gathering raw data from the construction sites in Poland. It is expected that local knowledge and easier access to on-site data will prove useful in the analysis and will stimulate progress in the field.

\section{References}

[1] Bamforth, P. B. (2007). CIRIA Report C660: Early-age thermal crack control in concrete. In CIRIA.

[2] Bamforth, P. B. (2018). CIRIA Report C766: Control of cracking caused by restrained deformation in concrete.

[3] De Schutter, G. (1999). Hydration and temperature development of concrete made with blast-furnace slag cement. Cement and Concrete Research, 29(1). https://doi.org/10.1016/ S0008-8846(98)00229-4

[4] Klemczak, B., \& Batog, M. (2016). Heat of hydration of lowclinker cements: Part I. Semi-adiabatic and isothermal tests at different temperature. Journal of Thermal Analysis and Calorimetry, 123(2). https://doi.org/10.1007/s10973-0154782-y

[5] Klemczak, B., \& Żmij, A. (2021). Insight into thermal stress distribution and required reinforcement reducing early-age cracking in mass foundation slabs. Materials, 14(3). https:// doi.org/10.3390/ma14030477

[6] Larisch, M. (2019). Fundamental Mechanisms of Concrete Bleeding in Bored Piles.

[7] LCPC. (2007). Recommandations pour la prévention des désordres dus à la réaction sulfatique interne - Guide technique.

[8] Liou, D. D. (1999). Thermal Effects in Large-Sized Diaphragm Wall. Journal of Performance of Constructed Facilities, 13(1). https://doi.org/10.1061/(asce)0887-3828(1999)13:1(17)

[9] Mitew-Czajewska, M., \& Tomczak, U. (2019). A case study of excavation induced displacements in dense urban area. Tunnels and Underground Cities: Engineering and Innovation Meet Archaeology, Architecture and Art- Proceedings of the WTC 2019 ITA-AITES World Tunnel Congress. https://doi. org/10.1201/9780429424441-626

[10] Mitew-Czajewska, Monika, \& Siemińska-Lewandowska, A. (2016). The second metro line in Warsaw - Lessons learnt. ITAAITES World Tunnel Congress 2016, WTC 2016, 4.

[11] PKN. (2008). PN-EN 1992-1-1:2008 - wersja polska. Eurokod 2 -Projektowanie konstrukcji z betonu -- Część 1-1: Reguty ogólne i reguły dla budynków.

[12] PKN. (2012). PN-EN 197-1:2012 - wersja polska. Cement -- Część 1: Skład, wymagania i kryteria zgodności dotyczące cementów powszechnego użytku.

[13] PKN. (2015). PN-EN 14216:2015-09 - wersja angielska. Cement -- Skład, wymagania i kryteria zgodności dotyczące cementów specjalnych o bardzo niskim cieple hydratacji.

[14] PKN. (2016). PN-EN 206+A1:2016-12 - wersja polska. Beton -Wymagania, właściwości, produkcja i zgodność.

[15] Poulos, H. G. (2020). Sven Hansbo Lecture: Deep foundation design - Issues, procedures and inadequacies. In Lecture Notes in Civil Engineering (Vol. 62). https://doi.org/10.1007/978-98115-2184-3_1 
[16] Sajadi, S. S. (2020). Thermal Behaviour Due to Heat of Hydration of Massive Concrete Underground Structures. Imperial College London.

[17] Siemińska-Lewandowska, A., Mitew-Czajewska, M., \& Tomczak, U. (2013). Various use of diaphragm walls for construction of multilevel road junction Design and monitoring of displacements. 18th International Conference on Soil Mechanics and Geotechnical Engineering: Challenges and Innovations in Geotechnics, ICSMGE 2013, 3.

[18] Siemińska-Lewandowska, A. (2010). Gtębokie wykopy. Projektowanie i wykonawstwo. Wydawnictwa Komunikacji i Lacznosci WKL.

[19] Siemińska-Lewandowska, Anna, \& Mitew-Czajewska, M. (2008). Design of deep excavations according to Eurocode 7 Studia Geotechnica et Mechanica, Vol. 30(nr 1-2), 207-214.

[20] Woyciechowski, P., Lukowski, P., \& Adamczewski, G. (2020). Thermal shock as a cause of cracking of concrete in massive bridge support elements - a case study. Roads and Bridges Drogi i Mosty, 19(4). https://doi.org/10.7409/rabdim.020.019

[21] Zych, M. (2018). Degree of external restraint of wall segments in semi-massive reinforced concrete tanks: Part I rectangular segments. Structural Concrete, 19(3). https://doi.org/10.1002/ suco.201700036 